\title{
Efficient Data Accessing through Heterogeneous ERP Solution
}

\author{
Radha Krishna Rambol \\ Asst. Professor, \\ Computer Science \& Engineering, \\ Panipat (India) \\ Ph.D. Scholar - The Tilka Manjhi \\ Bhagalpur University, Bhagalpur
}

\author{
Nesar Ahmad, PhD. \\ The Tilka Manjhi Bhagalpur \\ University, Bhagalpur
}

\author{
B.K. Sharma, PhD. \\ Principal Scientific Officer \& Head, \\ Software Development Centre, \\ Northern India Textile Research \\ Association, Ghaziabad (India)
}

\begin{abstract}
Application of Information Technology like ERP, Ecommerce, Data warehousing and Data mining are getting popularity in certain areas of industrial operations like Sales, production \& Production planning, EIS(Executive Information System),System Admin, Statutory requirements, Corporate portal, Customer care, maintenance, quality control, inventory management, finance, marketing and HRIS(HR \& Payroll). If we discuss to sustain competitive advantage in the dynamic market, an analysis at the micro level is essential e.g. Market and difference within markets, well-articulated understanding of market needs \& implications of these for all functions i.e.. On time Delivery (OTD) of raw material market projections, order scheduling, production planning \& control and after sales analysis apart from that big challenge is maintain the structured data like Multimedia and synchronization of access \& retrieval of data according to final output. ERP is the only solution to face all the changes emerged due to changed business environment and also for the problems due to preventing traditional system of working in terms of data accessibility for the heterogeneous platform through the ERP solution.
\end{abstract}

In Industry accurate planning and scheduling of orders, better date predictions, quick response to query and online detailed information of orders is must for doing business. As a result in the past few years at industry have invested in integrated systems, along with powerful hardware and software. The change from customized modular software to ERP is the current trend in Industry. Different type of industry are now going in for ERP/MRP (Material Resource Planning) and also web based software to enable them to remain competitive in this highly technology and competition driven economy. Effective application of Information technology in Industry has now become an integral part of their operations and a dire necessity for facing global challenges. Major benefits of ERP based systems are prompt and paperless communication, Better understanding of processes and business practices during implementation, an automatic discipline is imbibed in the users as lack of or delay in data entry by one department holds up the work in the next department. ERP helps in work center capacity analysis, work planning, advance planning of materials, stock management, warehouse management and reduced process cycle times resulting from using online purchase requisitions. By adopting ERP in industry system real time approach is possible to overcome the problem as mentioned above and also improve information system in terms of data access \& retrieval.

\section{Keywords}

Information Technology, Management Information System, E- commerce, Enterprise Resource Planning, MRP,
Data Warehousing and Data Mining, Inventory Management and Production Planning, EIS, HRIS, Customer care.

\section{INTRODUCTION}

Without Information technology we cannot move a bit. The rapid development in Information Technology has ushered in a revolution in all sphere of Industrial approach across the globe. IT applications are today's indispensable tools to boost productivity and drive maximum benefits. In other word we can say that the success of an organization depends on faster processing of access and retrieval of data, this requires a proper software system in terms of back-end, front-end with three tier system along with hardware to execute in proper way. Application of IT in Industry started more than a decade ago and today most of the applications of IT in Industry are shown in Fig.1. Every progressive organization has the only major objective to improve the efficiency in terms of access and retrieval with profitability. However, in today's competitive marketplaces, profitability is not only depends on increasing sales but also to minimize the time processing of access and retrieval of data. Above factors depends on the efficient resource management are consisting of the various recourses.

In the present time the improvement in terms of cost is only not a matter to called an efficient system. If we discuss to sustain competitive advantage in the dynamic market, an analysis at the micro level is essential e.g. market and difference within markets, well articulated understanding of market needs \& implications of these for all functions i.e. on time Delivery (O.T.D.) of raw material market projections, Order Scheduling, Production Planning and Control and After Sales. ERP is the only solution to face all the changes emerged due to changed business environment and also for the problems due to preventing traditional system by improving of access and retrieval.

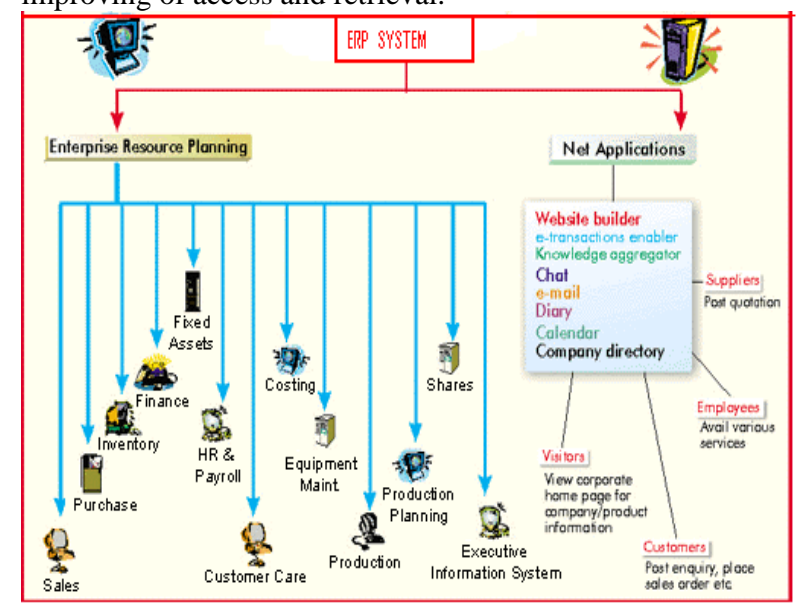

Fig.1: Network of General IT Application used in ERP Industry 


\subsection{Enterprise Resource Planning (ERP)}

Accurate planning and scheduling of orders, better date predictions, quick response to query and online detailed information of orders is must for doing business. As a result in the past few years many companies have invested in integrated systems, along with powerful hardware. The change from customized modular software to ERP is the current trend in Industry. Many Industries are now going for ERP web based software to enable them to remain competitive in this highly technology and competition driven economy. Effective application of Information Technology in Industry has now become an integral part of their operations and a dire necessity for facing global challenges.

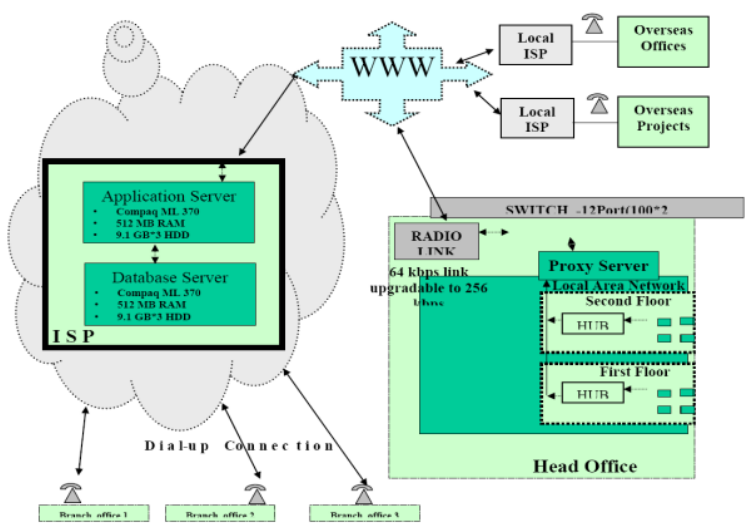

Fig.2: Data Communications in Web Based ERP System

Doing business today is actually an exercise in optimization. The business manager has a set of objectives to achieve in a given certain external operating environment and certain internal resources. This is not a question, whether he will achieve his objectives or not but to what extent he can achieve them given the conditions and that is what optimization is all about. Unfortunately business software used today lives a lot to be desired when it comes to optimization. Let's take the example of ERP in ty pical industry, General process of Data Communication in web based ERP system are shown in Fig. 2. ERP is like the data backbone of the company and generates data for a lot of activities of the company. ERP broadly covers Sales, Purchases, Production \& Production Planning, Procurement, Material, Finance, HRIS (HR \& Payroll), EIS (Executive Information System), Manufacturing, System Administration, Fixed Assets\& Costing, Customer Care, Corporate Portal, Inventory and Statutory requirements. The major departments wise activities are given in Table-1and process wise data Communications in ERP System of Industry also is given in Fig.3.

\begin{tabular}{|l|l|}
\hline $\begin{array}{c}\text { Major Functions/ } \\
\text { Departments }\end{array}$ & \multicolumn{1}{c|}{ Activities } \\
\hline - Sales & - SFA (Sales Force Automation) \\
& - Enquiry/Quotations \\
& - Sales order management \\
& - Billing \\
& - Stock transfer \\
& - Exports \\
\hline - Procurement & $\begin{array}{l}\text { - Product/Services management } \\
\text { - Sub-contracting management } \\
\end{array}$ \\
& -Supplier management \\
\hline
\end{tabular}

\begin{tabular}{|c|c|}
\hline - Materials & $\begin{array}{l}\text { - Inventory } \\
\text { - Inventory control } \\
\text { - Warehousing } \\
\text { - Dispatch } \\
\text { - Stock reconciliation }\end{array}$ \\
\hline - Financials & $\begin{array}{l}\text { - GL (General Ledger) } \\
\text { - AP/AR (Accounts Payable } \\
\text { and Receivables) } \\
\text { - Budgeting } \\
\text { - Vouchers and Day Books } \\
\text { - Trial Balance, Balance Sheet and } \\
\text { other } \\
\text { financial reports }\end{array}$ \\
\hline $\begin{array}{l}\cdot \text { HRIS } \\
\text { (HR \& Pay Roll) }\end{array}$ & $\begin{array}{l}\text { - Personnel Management } \\
\text { - Recruitment } \\
\text { - Appraisals } \\
\text { - Training } \\
\text { - Attendance recording and } \\
\text { management } \\
\text { - Payroll and Income Tax }\end{array}$ \\
\hline $\begin{array}{l}\text { Executive } \\
\text { Information } \\
\text { System (EIS) }\end{array}$ & $\begin{array}{l}\text { - Top level macro level reports for } \\
\text { the top management }\end{array}$ \\
\hline $\begin{array}{l}- \text { Statutory } \\
\text { Requirements }\end{array}$ & $\begin{array}{l}\text { (VAT, IT, Sales Tax, ESI, PF, Excise, } \\
\text { exports, Service Tax etc) }\end{array}$ \\
\hline - Manufacturing & $\begin{array}{l}\text { - Bill of material } \\
\text { - Machine allocation } \\
\text { - MRP } \\
\text { - Shop floor management } \\
\text { - Production Capacity planning } \\
\text { - Monthly Production schedules }\end{array}$ \\
\hline - Inventory & $\begin{array}{l}\text { - Receipt And Rejection Cycle } \\
\text { - Material Receipt At Stores } \\
\text { - Sales Cycle (Dispatch to customer) } \\
\text { - Stock Transfer Cycle } \\
\text {-Receipt Of Finished Goods }\end{array}$ \\
\hline - Corporate Portal & $\begin{array}{l}\text { - Knowledge management } \\
\text { - Management Dashboards } \\
\text { - Employee Self Service Applications } \\
\text { - Corporate chat } \\
\text { - Corporate web based e-mail } \\
\text { - PIM Utilities } \\
\text { - Technical Forums }\end{array}$ \\
\hline - Customer Care & $\begin{array}{l}\text { - After Sales Support Management } \\
\text { - AMC Management } \\
\text { - Complaint management }\end{array}$ \\
\hline $\begin{array}{l}\text { - Equipment } \\
\text { Maintenance }\end{array}$ & $\begin{array}{l}\text { - Maintenance Requisitions } \\
\text { - Service Order management } \\
\text { - Preventive and Breakdown } \\
\text { Maintenance }\end{array}$ \\
\hline $\begin{array}{l}\text { - System } \\
\text { Administration }\end{array}$ & $\begin{array}{l}\text { - Users and Role definition } \\
\text { - Users privileges and security } \\
\text { - Auto Back up Tool }\end{array}$ \\
\hline $\begin{array}{l}\text { - Fixed Assets and } \\
\text { Costing }\end{array}$ & $\begin{array}{l}\text { - Processing } \\
\text { - Asset Depreciation and Transactions } \\
\text { - Expenses allocation } \\
\text { - Budget/Forecast Analysis } \\
\text { - Multiple cost centers } \\
\text { - Product/Project costing }\end{array}$ \\
\hline
\end{tabular}




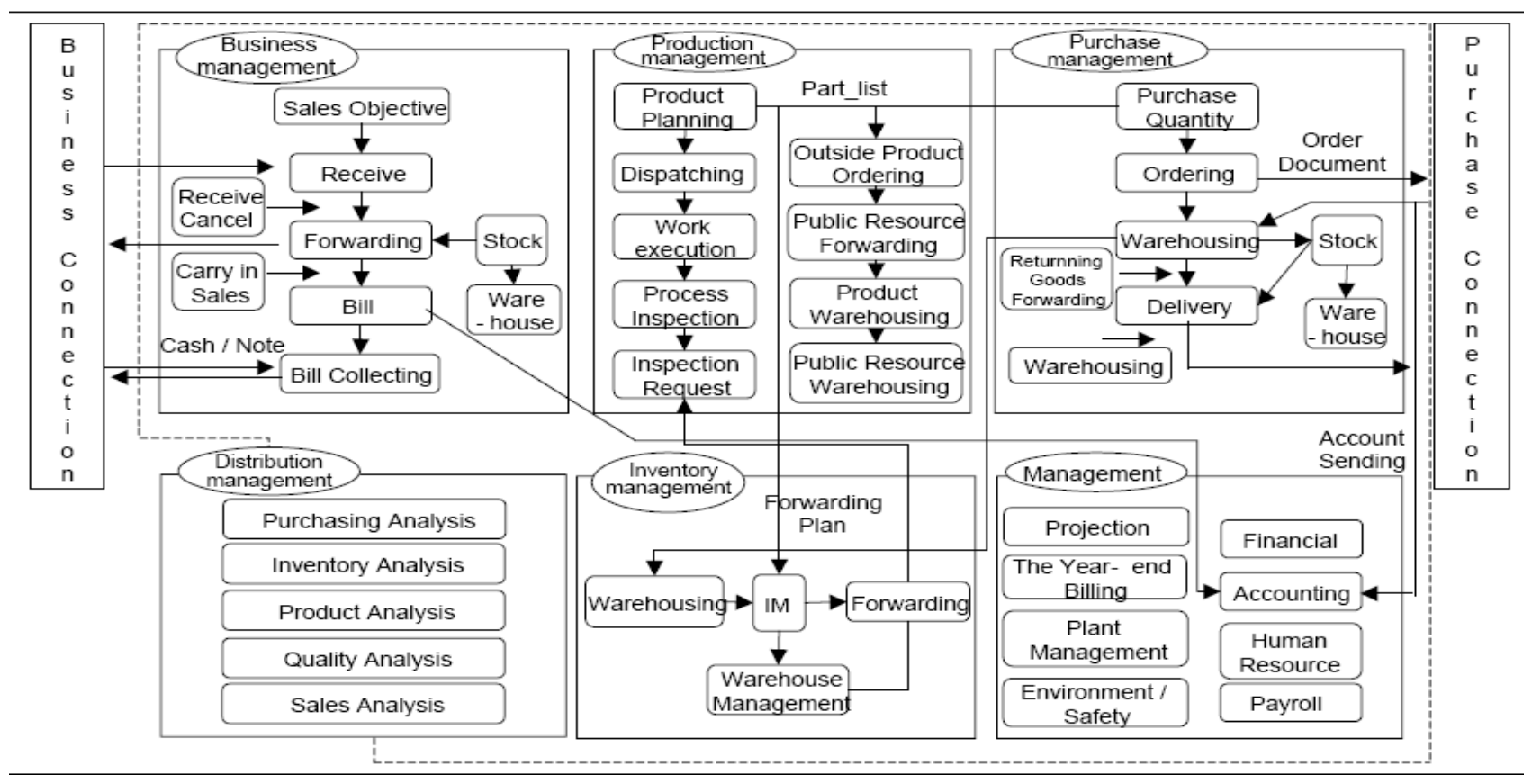

Fig.3: Process Wise Data Communications in ERP System of Industry

Source by: "Accurate information extraction from research papers using conditional random fields," in In HLTNAACL, 2004, pp. 329-336.

\section{BENEFITS OF ERP SOLUTIONS}

Organizations look for the benefits provided by ERP software such as the instant access of transactional information across the corporation. Such an information rich scenario permits organization to reduce inventory across multiple units/departments/plants; reduce cycle times from weeks to hours; and improve customer satisfaction by order of magnitude. All these translate to increased profitability or increase in marketing share and in turn such larger market capitalization.

ERP provides an opportunity for a corporation to operate as an agile entity to improve production/operation, customer service and customer satisfaction. The major benefits of ERP based systems are:

1. Prompt and paperless communication. ERP being an integrated system, user can check the status.

2. Better understanding of processes and business practices during implementation.

3. An automatic discipline is imbibed in the users as lack of or delay in data entry by one-department holds up the work in the next department.

4. Non-repetitive entry/posting of data.

5. In Production Planning and Control department, ERP helps in work center capacity analysis, work planning, advance planning of materials etc.

6. Stock management. (Raw material and finished material)

7. Batter utilization of Data Warehousing \& Data mining.

8. Better utilization of manpower.

9. Improves ability to commit delivery periods.

10. Effective working capital management through information visibility and effective receivables and payables management.
11. Reduced process cycle times resulting from using online purchase requisitions.

12. Order scheduling over a period of time and tracking delivery schedule.

\section{CONCLUSION}

Information Technology has changed drastically in the field of industrial management system. IT has changed the people's way of thinking, working and learning. It exists at every nook and corner of the society. It has really metamorphosed into world's latest global market representing an open market without having geographical or tariff barriers to reach to the customers all over the world. ERP systems are characterized by the aspects of information exchange, information sharing and information service. In the aspect of information interchange, ERP has linkage with EDI (Electronic Data Interchange); open architecture that enables exchange of information of different format and compatibility with different system software and platforms; globalization that implements global standards and best practice with multiple languages. In the aspect of information sharing, ERP can integrate and standardize business processes, link with groupware and EIS (Executive Information Systems). Therefore, ERP can make personnel in charge do real-time processing of business transactions with a lightened workload.

\section{REFERENCES}

[1] Dr. B.K. Sharma, D.K. Sharma, Application of Information Technology in Textile Wet Processing for Strategic Decision Making, International Journal of Management and System, Australia 
[2] Prof. S.M. Ishtiaque, Dr. B.K. Sharma, D.K. Sharma, Management Information System in Textile Wet Processing for batter decision-making presented at International Conference on IT in Textile Sector organized by Ministry of Textile, Govt. of India

[3] Dr. A.K. Srivastava, Dr. B.K. Sharma and R.S. Yadav, Marketing Information System in Textile Sector, The Indian Textile Journal, 111/8 (May, 2001)

[4] A.K. Srivastava, Dr. B.K. Sharma. A book on Computerized Records in Spinning Mils, NITRA Publication (2000)

[5] Dr. B.K. Sharma \& Prof. Abhay Bansal, Data Mining Tools and Techniques in Textile Industry for effective decision making and corrective action, Asian Textile Journal, Vol No. 15, No. 8, August 2006.
[6] Hyung Rim Choi, Hyun Soo Kim, Byung Joo park, An ERP approach for container terminal operating system, Marit. Pol. MGMT, Vol. 30, No. 3,197-210, JulySeptember 2003

[7] F. Peng and A. Mccallum, "Accurate information extraction from research papers using conditional random fields," in In HLTNAACL, 2004, pp. 329-336.

[8] S. Sekine, "On-demand information extraction," in Proceedings of the COLING/ACL on Main conference poster sessions, 2006, pp. 731-738.

[9] M. Banko, M. J. Cafarella, S. Soderland, M. Broadhead, and O. Etzioni, "Open information extraction from the web," in Proc. of IJCAI, 2007 